\title{
The phytoplankton community as a descriptor of environmental variability: a case study in five reservoirs of the Paraná River basin
}

\author{
A comunidade fitoplanctônica como descritora da variabilidade ambiental: um estudo \\ de caso em cinco reservatórios da bacia do alto rio Paraná
}

\section{Matheus Vieira da Silva ${ }^{1 *}$ (D), Jascieli Carla Bortolini ${ }^{2}$ (D) and Susicley Jati ${ }^{3}$ (D)}

\author{
${ }^{1}$ Programa de Pós Graduação em Biodiversidade e Conservação da Natureza, Laboratório de \\ Ecologia Aquática, Instituto de Ciências Biológicas, Universidade Federal de Juiz de Fora, \\ CEP 36036-900, Juiz de Fora, MG, Brasil \\ ${ }^{2}$ Departamento de Botânica, Instituto de Ciências Biológicas, Universidade Federal de Goiás, \\ Avenida Esperança, CEP 74690-900, Goiânia, GO, Brasil \\ ${ }^{3}$ Laboratório de Ecologia do Fitoplâncton, Núcleo de Pesquisas em Limnologia, Ictiologia e \\ Aquicultura (Nupélia), Universidade Estadual de Maringá, bloco H-90, CEP 87020-900, \\ Maringá, PR, Brasil \\ *e-mail: matheusvieirabio@hotmail.com
}

Cite as: Silva, M.V., Bortolini, J.C. and Jati, S. The phytoplankton community as a descriptor of environmental variability: a case study in five reservoirs of the Paraná River basin. Acta Limnologica Brasiliensia, 2022, vol. 34, e1.

\begin{abstract}
Aim: We aimed to characterize the structure of the phytoplankton community and identify the main environmental factors driving the community in five reservoirs constructed in the region of the high Paraná River. Methods: The phytoplankton and environmental variables were collected at the lacustrine region of the reservoir, between November 2013 and November 2014, with interval between collections ranged from 3 to 6 months. The richness and biomass of the phytoplankton community were measured as a response to the spatial and temporal environmental variability. Data from environmental variables was analyzed by Principal Component Analysis (PCA). Non-Metric Multidimensional Scaling Analyzes (NMDS) were performed on the richness and biomass data of the phytoplankton community. Results: We identified 80 taxa distributed in 11 taxonomic classes, from which Cyanobacteria and Chlorophyceae were best represented. We did not observe significant temporal variation for either environmental variables or attributes of the phytoplankton community, which may be related to the prolonged drought in this period in the Brazilian Southwest. Higher phytoplankton richness and biomass were found in the Três Irmãos (Tiete River), reservoir located in the most anthropized basin in the country. Cyanobacteria and dinoflagellates dominated the biomass in all reservoirs during the studied period. The Ilha Solteira, Jupiá and Porto Primavera reservoirs showed a tendency to decrease in the values of phytoplankton richness and biomass, and the reservoirs built in series in the Paraná River probably have strong interdependence, according to the CRCC concept. Conclusions: Spatial variation in phytoplankton attributes was influenced mainly by the position occupied by the reservoir in the hydrographic basin, water retention time (RT) and nutrient concentrations in each reservoir.
\end{abstract}

Keywords: community structure; cyanobacteria; Paraná River; reservoir; water retention time.

Resumo: Objetivo: Objetivamos caracterizar a estrutura da comunidade fitoplanctônica e identificar os principais fatores ambientais que impulsionam a comunidade em cinco reservatórios 
construídos na região do alto rio Paraná. Métodos: O fitoplâncton e as variáveis ambientais foram coletados na região lacustre do reservatório, entre novembro de 2013 e novembro de 2014, com intervalo entre as coletas de 3 a 6 meses. A riqueza e a biomassa da comunidade fitoplanctônica foram utilizadas como resposta à variabilidade ambiental espacial e temporal dos reservatórios. Os dados das variáveis ambientais foram analisados por meio de uma Análise de Componentes Principais (PCA). Foram realizadas Análises de Escalonamento Multidimensional Não-Métrico (NMDS) aos dados de riqueza e biomassa da comunidade fitoplanctônica. Resultados: Identificamos 80 táxons distribuídos em 11 classes, dos quais Cyanobacteria e Chlorophyceae foram os mais representados. Não observamos variação temporal significativa para variáveis ambientais ou atributos da comunidade fitoplanctônica, o que pode estar relacionado à prolongada estiagem neste período no sudeste brasileiro. Os maiores valores de riqueza e biomassa fitoplanctônica foram encontradas em Três Irmáos (Rio Tietê), reservatório localizado na bacia mais antropizada do país. Cianobactérias e dinoflagelados dominaram a biomassa em todos os reservatórios durante o período estudado. Os reservatórios de Ilha Solteira, Jupiá e Porto Primavera apresentaram tendência de diminuição nos valores de riqueza e biomassa fitoplanctônica, sendo que os reservatórios construídos em série no rio Paraná provavelmente possuem forte interdependência, de acordo com o conceito do CRCC. Conclusóes: A variação espacial dos atributos fitoplanctônicos foi influenciada principalmente pela posiçáo ocupada pelo reservatório na bacia hidrográfica, tempo de retenção de água (TR) e concentraçôes de nutrientes em cada reservatório.

Palavras-chave: estrutura da comunidade; cyanobacteria; Rio Paraná; reservatório; tempo de retenção da água.

\section{Introduction}

The major anthropogenic impacts on the rivers are habitat fragmentation and flow regime regulation, occasioned by dam construction (Winemiller et al., 2016). These are also the main global threats to the biological diversity of rivers and floodplains (Poff, 1997; Stanford \& Ward, 2001; Agostinho et al., 2007; Thomaz et al., 2007). The impacts of reservoir construction such as biodiversity loss, decrease in water quality of the river and social and economic changes, which may result in long-term effects, must be considered against its positive effects (Tundisi et al., 1999; Winemiller et al., 2016). The Paraná River, for example, is the second largest river of South America, with about $4,965 \mathrm{~km}$ in extension and a drainage basin that occupies approximately $891,000 \mathrm{~km}^{2}$, and is the most explored basin in terms of dam construction to hydroelectric generation in Brazil, producing about $70 \%$ of national electricity (Agostinho et al., 2007).

The construction of reservoirs disrupts the longitudinal gradient of rivers and causes conspicuous upstream physical and chemical modifications, including the attenuation of downstream flood pulses (Stanford \& Ward, 2001; Jati et al., 2017a). In addition, they are prone to nutrient enrichment, which often causes the proliferation of potentially harmful algal blooms, such as those of Cyanobacteria, compromising ecosystem services such as multiple water uses (Akhurst et al., 2017; Marques et al., 2019).
The phytoplankton community acts as an excellent model for environmental dynamics in reservoir areas and has an important role in the ecological processes of reservoirs, participating in carbon fixation, nutrient cycling and trophic interactions (Tundisi et al., 2008; Jati et al., 2017b). In addition, due to the high diversity of traits of these organisms and different limits of tolerance to environmental filters, they are an excellent tool to the diagnosis of environmental conditions, responding rapidly and efficiently to the impacts on aquatic systems (Reynolds et al., 2002; Lachi \& Sipaúba-Tavares, 2008; Bortolini et al., 2017a).

Studies developed in reservoirs point to hydrodynamic processes (advection, water retention time, vertical mixing regime) and climatic factors (precipitation and wind), besides chemical and physical water conditions, as drivers of the structure and dynamics of phytoplankton (Calijuri et al., 2002; Silva et al., 2005; Nogueira et al., 2010; Perbiche-Neves et al., 2011). Thus, investigating the phytoplankton community in response to environmental variability may contribute to understand the dynamics of aquatic communities and serve as subside in reservoir management. Although studies on phytoplankton in reservoirs are abundant in different Brazilian regions, the present study can contribute to expanding the knowledge about the phytoplankton community in reservoirs of the upper Paraná River.

We monitored spatial and temporal the variation of phytoplankton richness and biomass in five reservoirs constructed in the Upper Paraná River region for a year. We hypothesized that the main 
forces driving the phytoplankton community structure would be water retention time and the trophic conditions of each reservoir, associated to the geographic position each reservoir occupies in the hydrographic basin.

\section{Material and Methods}

\subsection{Study area}

The study was carried out in five reservoirs located at the upper Paraná River basin (Figure 1): Ilha Solteira reservoir - R1 (20²1' S/5120' W),
Jupiá reservoir - R2 $\left(20^{\circ} 45^{\prime} \mathrm{S} / 51^{\circ} 37^{\prime} \mathrm{W}\right)$, Porto Primavera reservoir - R3 (22。28' S/52056' W), Três Irmãos reservoir - R4 (20³9' S/5116' W) and Rosana reservoir - R5 (22。36' S/52。51' W). The water residence time and main morphometric characteristics of each reservoir are presented in Table 1.

The Ilha Solteira, Jupiá and Porto Primavera reservoirs were constructed in cascade in the Paraná River, and Ilha Solteira and Jupiá form, together, the sixth larger hydroelectric complex in the world (Ling, 2013). The Três Irmãos and Rosana reservoirs

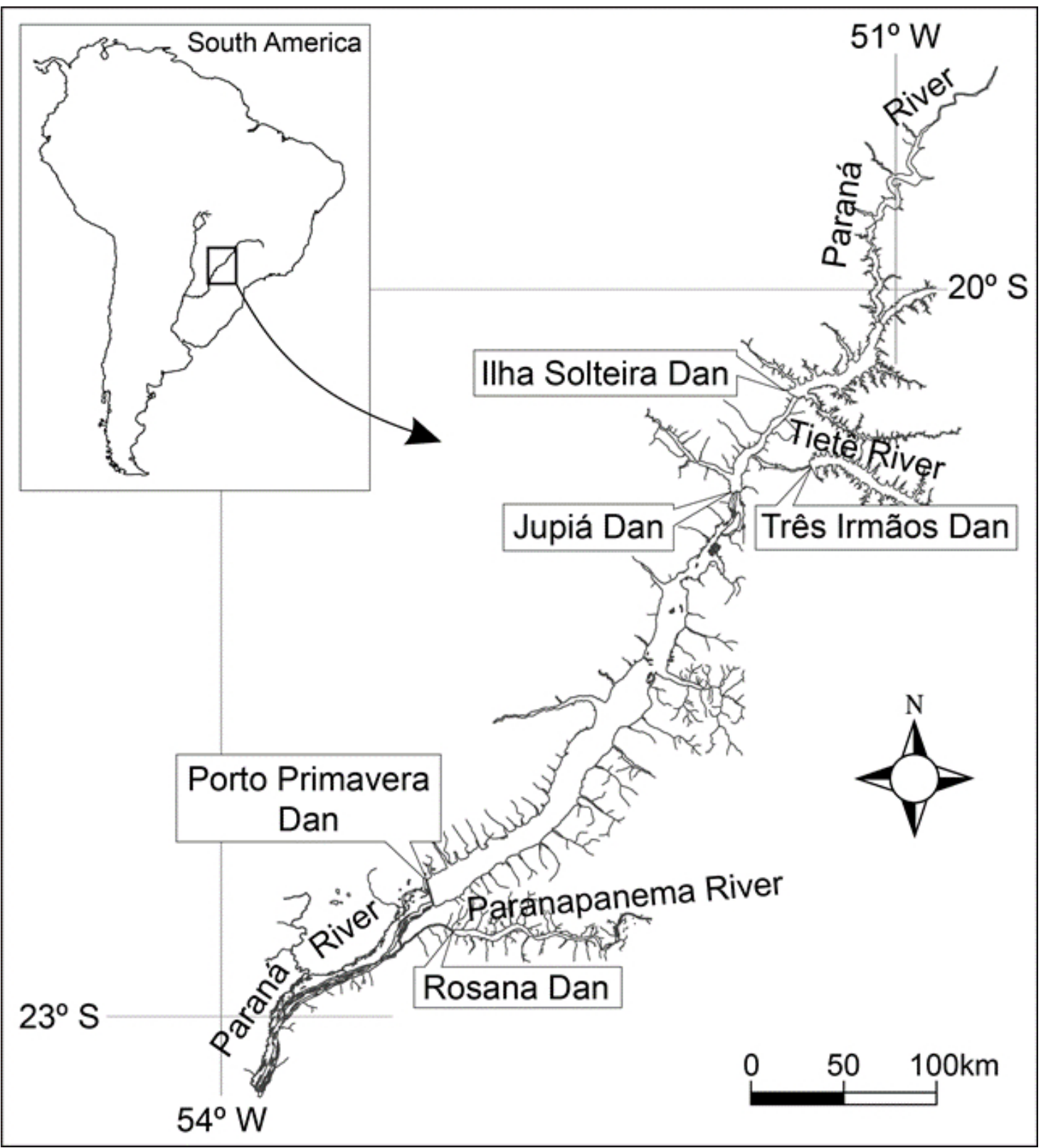

Figure 1. Map of the study area with the localization of the Ilha Solteira, Jupiá, Porto Primavera (Paraná River), Três Irmãos (Tietê River) and Rosana (Paranapanema River) reservoirs. Graphic art: Jaime Luiz Lopes Pereira. 
Table 1. Water residence time and morphometric characteristics of each reservoir (RT - residence time).

\begin{tabular}{|c|c|c|c|c|c|c|}
\hline Dam & & River & $\begin{array}{c}\text { Start of } \\
\text { operations }\end{array}$ & RT (Days)* & Area $\left(\mathrm{km}^{2}\right)$ & Height (m) \\
\hline Ilha Solteira & R1 & Paraná & 1973 & 47.6 & 1.195 & 74 \\
\hline Jupiá & $\mathrm{R} 2$ & Paraná & 1969 & 6.9 & 330 & 43 \\
\hline Primavera & R3 & Paraná & 1999 & 33.9 & 2.250 & 38 \\
\hline Três Irmãos & $\mathrm{R} 4$ & Tietê & 1993 & 217.9 & 785 & 82 \\
\hline Rosana & R5 & Paranapanema & 1987 & 18.6 & 261 & 30 \\
\hline
\end{tabular}

*Data obtained from Agostinho et al. (2007) and Stevauxet al. (2009).

are located in the Tietê and Paranapanema rivers, respectively, and are the last reservoirs of two series of dams that drain the most populated and industrialized region of the country (CESP, 1998).

The studied region has a tropical climate - Aw (Köppen's classification), which is characterized by a rainy summer (December-March) and dry winter (June-September), with an annual mean temperature of $23.7^{\circ} \mathrm{C}$ and annual rainfall of $1,300 \mathrm{~mm}$ (CESP, 1998).

\subsection{Sampling and analyses of environmental variables and phytoplankton}

Samplings of the environmental variables and phytoplankton were simultaneously performed at the subsurface of the lacustrine zone of each reservoir, in November 2013 and in February, August, and November $2014(\mathrm{n}=20)$. The quantitative phytoplankton samples were taken directly with bottles and fixed with acetic Lugol's solution. For taxonomic identification of the phytoplankton, samples were also taken with a plankton net $(15 \mu \mathrm{m})$ and fixed with Transeau solution (Bicudo $\&$ Menezes, 2006).

The phytoplankton density was estimated using an inverted microscope according to the method proposed by Utermöhl (1958). We calculated density according to APHA (1995) and estimated biomass from the biovolume, which we obtained from the multiplication of density and cellular volume of each organism. We calculated the cellular volume comparing organism morphology with geometric shapes, according to Sun \& Liu (2003). We considered species richness as the total number of taxa registered in each quantitative sample. The algae species were grouped in two size groups: nanoplankton $(2-20 \mu \mathrm{m})$ and microplankton (21$200 \mu \mathrm{m})$ according to Reynolds (2006).

The environmental variables measured were: water temperature (WT), $\mathrm{pH}$, electrical conductivity (Cond) and dissolved oxygen (DO). These variables were obtained in situ using portable digital potentiometers. Water turbidity
(Turb) was measured by a mass turbidimeter. The maximum depth was also obtained $\left(\mathrm{Z}_{\max }\right)$. Total phosphorus (TP, Golterman et al., 1978) and total Kjeldahl nitrogen (TN; Mackereth et al., 1978) concentrations were estimated.

\subsection{Data analyses}

We calculated descriptive statistics as mean (central trend measure) and coefficient of variation for abiotic data. We performed a Principal Components Analysis (PCA) to summarize the environmental variability of the reservoirs according to abiotic conditions registered during the study period. To evaluate the similarity among reservoirs and sampled months for richness and biomass values of the phytoplankton community, we performed a Non-metric Multidimensional Scaling Analysis (NMDS). NMDS distances were calculated through the Bray-Curtis similarity index, and the distortion of the resolution was expressed by the value of $S$ (stress) (Clarke, 1993). To verify the existence of significant differences in phytoplankton richness and biomass among reservoirs and months, we performed a Multivariate Permutational Variation Analysis (PERMANOVA - Anderson, 2001). To verify the concordance between phytoplankton community (richness and biomass matrix) and environmental variability (abiotic variables) of the reservoirs, we performed a Procrustes test, where a distance matrix (Bray-Curtis) was ordinated with an Analysis of Principal Coordinates (PCoA). For this analysis, data (richness, biomass and abiotic variables) were $\log$-transformed $(\log x+1)$, except for $\mathrm{pH}$. We established a significance threshold of $\mathrm{p}<0.05$. All the analyses were performed in the $\mathrm{R}$ environment (R Development Core Team, 2017) with the package vegan (Oksanen et al., 2017).

\section{Results}

The higher mean values of electric conductivity were verified in reservoir $\mathrm{R} 3$, while the higher mean values of turbidity were registered in reservoir R4. The higher $\mathrm{Z}_{\max }$ was registered in reservoir $\mathrm{R} 5$. 
Low variability in values of water temperature, dissolved oxygen and $\mathrm{pH}$ were registered. The highest total nitrogen concentrations were registered in reservoir R1 in November $2013\left(762\right.$ 冈g $\left.1^{-1}\right)$. The reservoirs in the Paraná River (R1, R2 and R3) presented higher phosphorous concentrations, highlighting reservoir R2 in February 2014 with $21.03 \mathbb{~ g ~}^{-1}$ (Table 2).

We did not observe a well-defined temporal variation of the abiotic data. The PCA explained $54 \%$ of environmental variability, in the axis $1(28 \%)$ was positively correlated to DO $(0.38)$ and turbidity (0.38), with the separation of reservoirs R4 and R5. This axis was negatively correlated to WT (-0.66) and TN (-0.54), most samples of the reservoir R3 being segregated. The PCA axis $2(26 \%)$ was positively correlated to $\mathrm{Z}_{\max }(0.54)$ and negatively correlated with $\mathrm{pH}(-0.49)$. Most samples from August and November 2014 were ordered positively correlated in axis 2 (Figure 2).

Phytoplankton taxonomic composition was similar in all reservoirs. We identified 80 taxa, distributed in eleven taxonomic classes: Cyanobacteria (30), Chlorophyceae (17), Euglenophyceae (8), Zygnematophyceae (7), Bacillariophyceae (6), Trebouxiophyceae (4), Cryptophyceae (2), Dinophyceae (2), Coscinodiscophyceae (2), Chrysophyceae (1) and Chlamydophyceae (1). Genera Chroococcus Nägeli (Cyanobacteria) and Staurastrum Meyen ex Ralfs (Zygnematophyceae) were those best represented, with 5 species.
Considering the size of the organisms, we found that the phytoplankton communities in all reservoirs were formed largely by nanoplanktonic taxa (Figure 3).

The reservoir R4 presented the highest values of species richness during all of the studied period, with a maximum number of species registered in February 2014 (45 taxa). Lowest species richness values were observed in reservoirs $\mathrm{R} 5$, with 9 taxa in August 2014, and R3, with 11 taxa in

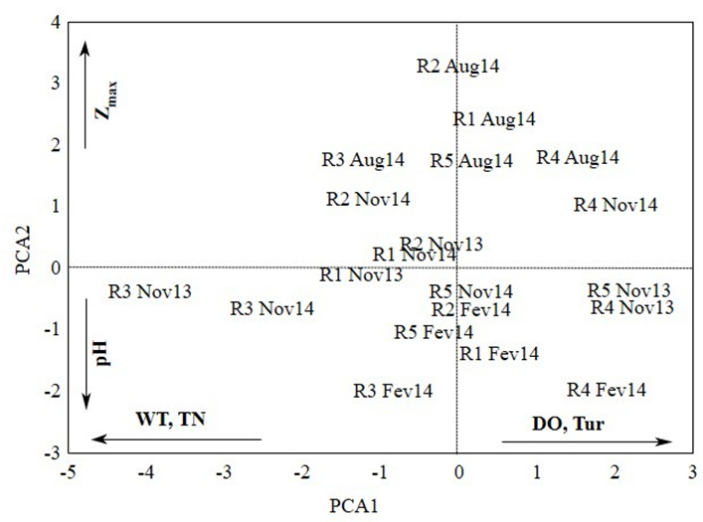

Figure 2. Dispersion of month-local scores along the first two axes of the PCA using the abiotic variables in the reservoirs (Ilha Solteira Reservoir - R1; Jupiá Reservoir R2; Porto Primavera Reservoir R3; Três Irmãos Reservoir - R4; Rosana Reservoir - R5). DO: dissolved oxygen; Cond: electrical conductivity; WT: water temperature; Turb: Turbidity; $\mathrm{Z}_{\max }$ : depth).

Table 2. Mean values and coefficients of variation - in \% (in brackets) of the abiotic variables during the period between November 2013 and November 2014 in the reservoirs.

\begin{tabular}{cccccc}
\hline & R1 & R2 & R3 & R4 & R5 \\
\hline $\mathrm{Z}_{\max }(\mathrm{m})$ & 27.2 & 25.6 & 38.0 & 26.4 & 36.7 \\
& $(1.3)$ & $(24.5)$ & $(7.1)$ & $(2.4)$ & $(33.5)$ \\
$\mathrm{WT}\left({ }^{\circ} \mathrm{C}\right)$ & 26.8 & 25.9 & 27.5 & 27.4 & 27.8 \\
& $(10.9)$ & $(11.6)$ & $(8.9)$ & $(7.7)$ & $(8.4)$ \\
$\mathrm{DO}\left(\mathrm{mg} \mathrm{l}^{-1}\right)$ & 8.2 & 8.8 & 8.7 & 8.0 & 7.8 \\
& $(7.1)$ & $(6.0)$ & $(7.3)$ & -22 & $(6.3)$ \\
$\mathrm{pH}$ & 7.6 & 7.5 & 8.5 & 7.4 & 7.5 \\
& $(12.2)$ & $(12.5)$ & $(15.9)$ & $(11.8)$ & $(12.1)$ \\
Cond $\left(\mu \mathrm{S} \mathrm{cm}^{-1}\right)$ & 63.0 & 64.8 & 160.4 & 50.3 & 51.7 \\
& $(3.7)$ & $(2.9)$ & $(4.1)$ & $(12.9)$ & $(15.2)$ \\
Turb $(\mathrm{NTU})$ & 1.71 & 4.5 & 2.2 & 7.7 & 2.8 \\
& $(108.6)$ & $(45.2)$ & $(126.4)$ & $(38.5)$ & $(51.8)$ \\
$\mathrm{TN}\left(\mu \mathrm{I} \mathrm{I}^{-1}\right)$ & 760.3 & 679.7 & 703.0 & 322.0 & 528.1 \\
& $(8.7)$ & $(7.0)$ & $(21.0)$ & $(42.5)$ & $(8.0)$ \\
$\mathrm{TP}\left(\left.\mu \mathrm{g} \mathrm{|}\right|^{-1}\right)$ & 8.3 & 16.4 & 8.3 & 5.6 & 5.7 \\
& $(26.0)$ & $(20.1)$ & $(38.2)$ & $(19.1)$ & $(21.4)$ \\
\hline
\end{tabular}

R1-Ilha Solteira Reservoir, R2-Jupiá Reservoir, R3-Porto Primavera Reservoir, R4-Três Irmãos Reservoir, R5-Rosana Reservoir. $\left(\mathrm{Z}_{\text {max }}\right.$ : depth; WT: water temperature; DO: dissolved oxygen; Cond: electrical conductivity; Turb: turbidity; TN: total nitrogen; TP: total phosphorus). 
November 2014. Cyanobacteria, chlorophyceans, euglenophyceans and diatoms contributed importantly to phytoplankton richness in all reservoirs (Figure 4).

During the study period, cyanobacteria and dinophyceans, represented by large species, were predominant in terms of biomass. The highest values of phytoplankton biomass were observed in reservoirs R1 and R4 during the entire study period, with a maximum value in R4 in August $2014\left(4,79 \mathrm{~mm}^{3} \mathrm{~L}^{-1}\right)$ due to the predominance

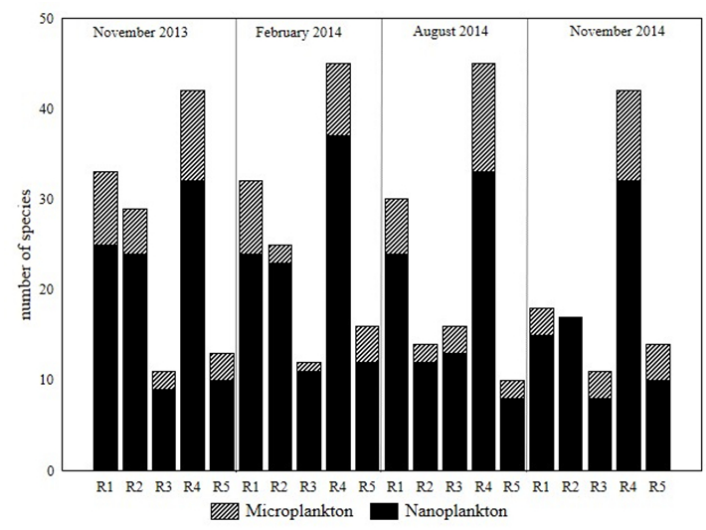

Figure 3. Temporal and spatial distribution of phytoplankton community size structure in reservoirs studied between November 2013 and November 2014 (Ilha Solteira Reservoir - R1; Jupiá Reservoir - R2; Porto Primavera Reservoir - R3; Três Irmãos Reservoir - R4; Rosana Reservoir - R5).

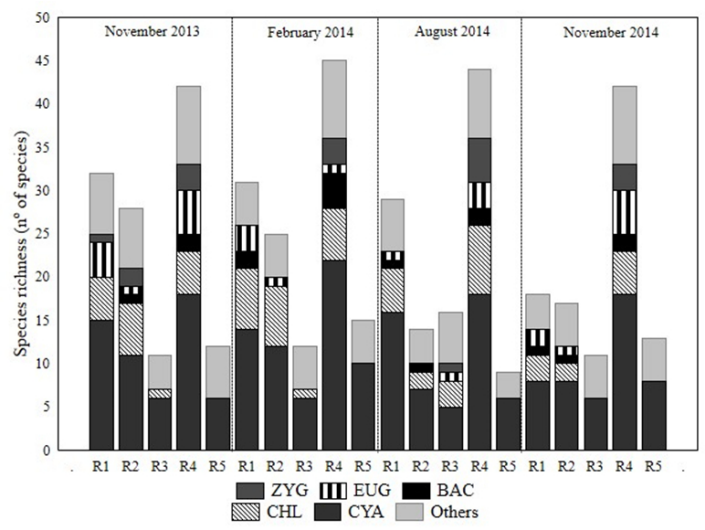

Figure 4. Temporal and spatial distribution of phytoplankton species richness in the reservoirs studied between November 2013 and November 2014 (ZYG- Zygnematophyceae; EUG- Euglenophyceae; BAC-Bacillariophyceae; CHL-Chlorophyceae; CYA-Cyanobacteria; Ilha Solteira Reservoir - R1; Jupiá Reservoir - R2; Porto Primavera Reservoir - R3; Três Irmãos Reservoir - R4; Rosana Reservoir - R5). of Radiocystis fernandoi Kom. and Kom.-Legn, Microcystis aeruginosa (Küt) Kützing and Peridinium sp., while lower values were observed in R2, R3 and R5 for the entire period, with R5 in August 2014 presenting the lowest value $\left(0.09 \mathrm{~mm}^{3} \mathrm{~L}^{-1}\right)$ (Figure 5).

According to the NMDS (stress $=0.13$ ), there was a clear separation in phytoplankton richness among reservoirs (Figure 6a). The PERMANOVA results showed the spatial difference between the reservoirs ( $p=0.001)$, but did not indicate temporal differences $(p=0.999)$. As to species richness, reservoirs R1, R2 and R3 are more similar among them, while reservoirs R4 and R5 are different from each other and from the rest of reservoirs. According to the NMDS (stress $=0.1$ ), there was also a separation among reservoirs for phytoplankton biomass (Figure 6b).

The PERMANOVA confirmed difference in biomass among the reservoirs $(p=0.001)$, but not among months $(\mathrm{p}=0.998)$. As to biomass, R1, R2, R3 and R5 present higher similarity and R4 is shown segregated in the ordination. Procrustes showed that both phytoplankton species richness ( $\mathrm{r}$ $=0.53 ; \mathrm{p}=0.005)$ and biomass $(\mathrm{r}=0.48 ; \mathrm{p}=0.01)$ were concordant with environmental variability of the reservoirs.

\section{Discussion}

We observed a significant spatial variation of the phytoplankton attributes between the

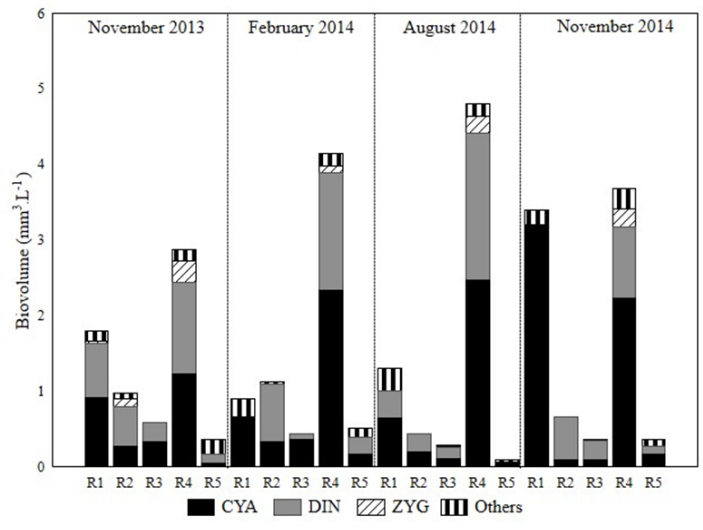

Figure 5. Temporal and spatial distribution of phytoplankton biomass in the reservoirs studied between November 2013 and November 2014 (CYA-Cyanobacteria; DIN-Dinophyceae; ZYG- Zygnematophyceae; Ilha Solteira Reservoir - R1; Jupiá Reservoir - R2; Porto Primavera Reservoir - R3; Três Irmãos Reservoir - R4; Rosana Reservoir - R5). 

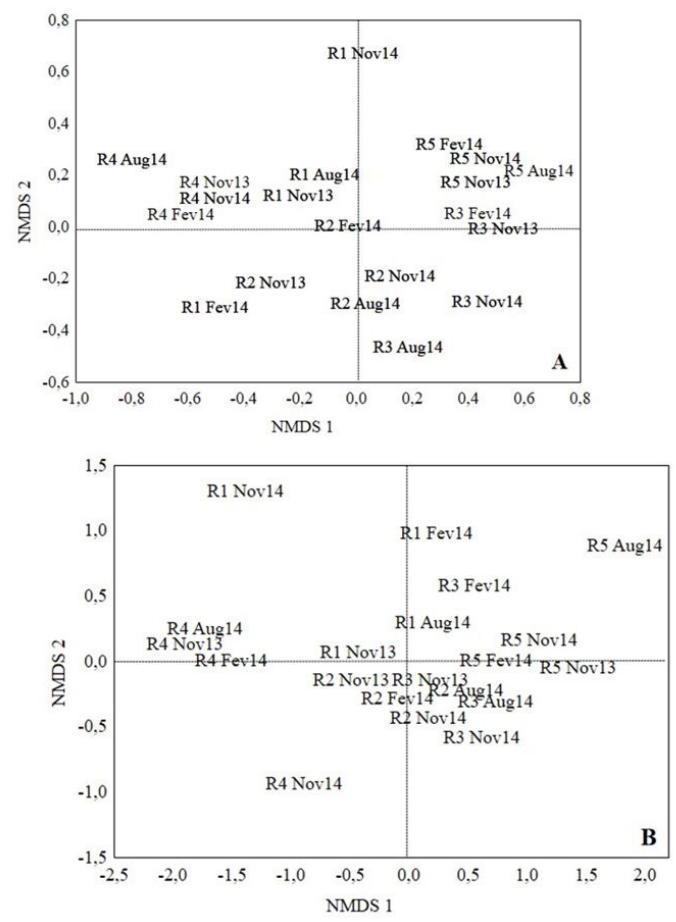

Figure 6. Non-Metric Multidimensional Scaling (NMDS) for the distribution of phytoplankton richness (a) and biomass (b) in the reservoirs.

sampled reservoirs. However, temporal variation in the structure of the phytoplankton community presented no seasonal pattern. The period in which this study was developed (2013-2014) was characterized as the longest drought period in the Brazilian southeast, with a precipitation deficit of $300 \mathrm{~mm}$ (Coelho et al., 2016; Marengo et al., 2015). Possibly, this climatic anomaly influenced the absence of seasonal patterns. Normally, summers would cause flooding periods in the main rivers of the Paraná River hydrographic basin, influencing environmental filters and consequently the phytoplankton community in these systems (Bortolini et al., 2017b; Jati et al., 2017b).

Characteristics of each reservoir as water retention time, geographic position or anthropic activities developed in their drainage basins are capable of producing direct or indirect effects on the structure and dynamics of the phytoplankton community (Barbosa et al., 1999; Padisák et al., 2000). These characteristics have probably influenced the spatial variation of phytoplankton attributes observed in this study.

Phytoplankton of the studied reservoirs was mainly represented by nanoplankton species in all samples. This fraction of the community is favored in their development due to their high surface- volume ratio, which allows for rapid and efficient absorption of the available nutrients, even in an oligotrophic at mesotrophic environment (Lewis Junior, 1976; Naselli-Flores et al., 2007). This contribution is very important because even though these organisms represent low biomass values, they are the ones that effectively participate in the process of energy transference to higher levels of the trophic chain (Meira et al., 2017).

Reservoirs represent interruptions in the river continuum. Consequently, there may be a decrease in the concentration of nutrients and suspended solids along the longitudinal axis of a river, resulting in reduced primary production (Moura et al., 2013). Thus, when reservoirs are constructed in series, the position they occupy along the river may help to explain the functioning, trophy and dynamics of their phytoplankton communities (Barbosa et al., 1999; Padisák et al., 2000).

In this study, reservoirs constructed in series in the Paraná River (R1, R2 and R3) presented, for most sampling events, lower values for richness and biomass the phytoplankton and a tendency reduction of these values along the longitudinal gradient of the river, from reservoir R1 to R2 and then to R3. This is probably because the downstream reservoir is strongly influenced by the upstream reservoir, which retains part of the seston that should be exported downstream (Perbiche-Neves et al., 2011; Bovo-Scomparin et al., 2013), altering the quantity and quality of organic carbon that is passively transported downstream in a reservoir cascade (Engel et al., 2019).

The RT presented by a reservoir interferes directly with the development of the phytoplankton community so that increasing RT is one the main drivers of biomass increment (Soares et al., 2008; Perbiche-Neves et al., 2011; Engel et al., 2019). In our study, reservoirs R1, R2 and R3 presented low RT, between 7 and 48 days, due to the high water flow of the Paraná River. These two factors associated to the interrelation between these reservoirs was a determinant factor for the low values and spatial variation of the phytoplankton attributes.

Reservoirs R4 (Três Irmãos) and R5 (Rosana) are the last ones in a long series of reservoirs constructed in the Tietê and Paranapanema Rivers, respectively, which are important tributaries of the Paraná River. According to the cascading reservoir continuum concept (CRCC), the last reservoirs in a series are less productive than the first ones (Barbosa et al., 1999). Indeed, R5 presented low values of 
phytoplankton attributes, with temporal variation similar to that observed in the main channel of the Paraná River. On the other hand, R4 was more productive, besides presenting high species richness and a different taxonomic composition when compared to the other reservoirs. In R4, most of phosphorous is not available in the environment, but incorporated in the phytoplankton biomass, producing high levels of biogenic turbidity.

R4 and R5 concentrate environmental information from different hydrographic basins. The Tietê basin is the most populated basin of the country, and consequently the most anthropically impacted. On the other hand, the Paranapanema basin presents a lower charge of pollutants (Barrella \& Petrere Junior, 2003). Apart from trophic differences, R5 shows a short RT (19 days), similar to that of the Paraná River reservoirs. R4 has a water retention time of 218 days, the longest among the studied reservoirs. The synergism between higher nutrient availability and higher RT was probably what favored the development of the phytoplankton community, expressed in the higher values of phytoplankton attributes.

We registered the accumulation of colonial Cyanobacteria biomass in all studied reservoirs, with the dominance of taxa such as Microcystis aeruginosa Kütz. and Radiocystis fernandoi Kom. and Kom. -Legn. This is commonly reported in the literature for reservoirs of tropical regions (Silva et al., 2005; Dantas et al., 2011). The efficiency in exploring environmental resources, the capacity to regulate their position in the water column, lower predation rates (Fialkowska \& Pajdak-Stós, 2002), toxigenic potential and the fact that they constitute a low quality feeding resource (Ferrão-Filho et al., 2002; Panosso et al., 2003) constitute competitive advantages of Cyanobacteria when compared to other phytoplankton groups (Padisák et al., 2009; Tang et al., 2018).

Beside Cyanobacteria, dinoflagellates were important contributors to biomass in all the studied reservoirs. This group comprises flagellated unicellular algae with wide physiological plasticity, high motility and high mixotrophic capacity (Kruk \& Segura, 2012). Nevertheless, the observed biomass values are due to their large dimensions, and not to the development of large populations. Among dinophyceae, Ceratium furcoides (Levander) Langhans (Dinophyceae) was registered in all reservoirs. This is an invasive species pointed as capable of interfering with the structure and dynamics of the phytoplankton community, apart from influencing in the energy transference to higher levels of the food chain (Cavalcante et al., 2016; Jati et al., 2017b; Crossetti et al., 2019).

The dominance of Cyanobacteria biomass and the presence of the exotic species Ceratium furcoides causes concern. These undesirable organisms may put ecosystem services provided by reservoirs at risk and may be exported downstream, where there is a large environmental protection area that stretches for approximately $200 \mathrm{~km}$ along the Paraná River (Environmental Protection Area of the Islands and Floodplain of the Paraná River, Ilha Grande National Park, State Park of the Ivinhema River Floodplain), contributing to biotic homogenization and biodiversity decrease (Bovo-Scomparin et al., 2013; Bortolini et al., 2017a).

We conclude that, in the absence of seasonal environmental variability caused by drought, the variation of phytoplankton attributes was probably influenced by the spatial characteristics of each reservoir, as position occupied in the hydrographic basin, water retention time (RT) and anthropic activities developed in the basin, which are mainly translated in nutrient concentration.

\section{Acknowledgements}

This work was supported by the Coordenação de Aperfeiçoamento de Pessoal de Nível Superior (CAPES) - Finance Code 001 (fellowship conceding to MVS). We thank to the NUPELIA (Núcleo de Pesquisas em Limnologia, Ictiologia e Aquicultura) of UEM (Universidade Estadual de Maringá) for logistical and financial support, Limnology Basic Laboratory/Nupelia for abiotic data.

\section{References}

Agostinho, A.A., Gomes, L.C., \& Pelicice, F.M., 2007. Ecologia e manejo de recursos pesqueiros em reservatórios do Brasil. Maringá: Eduem, 501 p.

Akhurst, D.J., Jones, G.B., Clark, M., \& ReicheltBrushett, A., 2017. Effects of fish and macrophytes on phytoplankton and zooplankton community structure in a subtropical freshwater reservoir. Limnologica, 62, 5-18. http://dx.doi.org/10.1016/j. limno.2016.09.009.

American Public Health Association - APHA, 1995. Standard methods for the examination of water and waste-water. Washington: American Public Health Association.

Anderson, M.J., 2001. A new method for non-parametric multivariate analysis of variance. Austral Ecol., 26, 32-46.

Barbosa, F.A.R., Padisák, J., Espíndola, E.L.G., Borics, G., \& Rocha, O., The Cascading Reservoir 
Continuum Concept (CRCC) and its application to the river Tietê-Basin, São Paulo State, Brazil. In: Tundisi JG, \& Straskraba M, eds. Theoretical reservoir ecology and its applications. São Carlos: International Institute of Ecology, Brazilian Academy of Sciences and Backhuys Publishers, 425-437, 1999.

Barrella, W., \& Petrere Junior, M.J., 2003. Fish community alterations due to pollution and damming in Tiete and Paranapanema Rivers (Brazil). River Res. Appl., 19(1), 59-76. http://dx.doi. org/10.1002/rra.697.

Bicudo, C.E.M., \& Menezes, M., Gêneros de algas de águas continentais do Brasil (chave para identifcação e descriçōes) (2. ed.). São Carlos: RIMA, 2006.

Bortolini, J.C., Pineda, A., Rodrigues, L.C., Jati, S., \& Velho, L.F.M., 2017a. Environmental and spatial processes influencing phytoplankton biomass along a reservoirs-river floodplain lakes gradient: a metacommunity approach. Freshw. Biol. 62(10), 1756-1767. http://dx.doi.org/10.1111/fwb.12986.

Bortolini, J.C., Train, S., \& Rodrigues, L.C., 2017b. The variability in the hydrosedimentological regime supports high phytoplankton diversity in floodplain: a 12-year survey of the Upper Paraná River. J. Limnol., 76(3), 591-604. http://dx.doi.org/10.4081/ jlimnol.2017.1509.

Bovo-Scomparin, V.M., Train, S., \& Rodrigues, L.C., 2013. Influence of reservoirs on phytoplankton dispersion and functional traits: a case study in the Upper Paraná River, Brazil. Hydrobiologia, 702(1), 115-127. http:// dx.doi.org/10.1007/s10750-012-1313-8.

Calijuri, M.C., Santos, A.C.A., \& Jati, S., 2002. Temporal changes in the phytoplankton community structure in a tropical and eutrophic reservoir (Barra Bonita, SP-Brazil). J. Plankton Res., 24(7), 617-634. http://dx.doi.org/10.1093/plankt/24.7.617.

Cavalcante, K.P., Cardoso, L.S., Sussella, R., \& Becker, V., 2016. Towards a comprehension of Ceratium (Dinophyceae) invasion in Brazilian freshwaters: autecology of $C$. furcoides in subtropical reservoirs. Hydrobiologia, 771(1), 265-280. http://dx.doi. org/10.1007/s10750-015-2638-x.

Clarke, K.R., 1993. Non-parametric multivariate analyses of changes in community structure. Austral Ecol., 18(1), 117-143. http://dx.doi. org/10.1111/j.1442-9993.1993.tb00438.x.

Coelho, C.A.S., Oliveira, C.P., Ambrizzi, T., Reboita, M.S., Carpenedo, C.B., Campos, J.L.P.S., Tomaziello, A.C.N., Pampuch, L.A., Custódio, M.S., Dutra, L.M.M., Rocha, R.P., \& Rehbein, A., 2016. The southeast Brazil austral summer drought: regional scale mechanisms and teleconnections. Clim. Dyn., 46(11-12), 3737-3752. http://dx.doi.org/10.1007/ s00382-015-2800-1.

Companhia Hidrelétrica de São Paulo - CESP, 1998. Conservação e manejo nos reservatórios: limnologia, ictiologia e pesca. São Paulo: Série Divulgação e Informação, $220 \mathrm{p}$.

Crossetti, L., Bicudo, D.C., Bini, L.M., Dala-Corte, R.B., Ferragut, C., \& Bicudo, C.E.M., 2019. Phytoplankton species interactions and invasion by Ceratium furcoides are influenced by extreme drought and water-hyacinth removal in a shallow tropical reservoir. Hydrobiologia, 831(1), 71-85. http:// dx.doi.org/10.1007/s10750-018-3607-y.

Dantas, E.W., Moura, A.N., \& Bittencourt-Oliveira, M.C., 2011. Cyanobacterial blooms in stratified and destratified eutrophic reservoirs in semi-arid region of Brazil. An. Acad. Bras. Cienc., 83(4), 1327-1338. http://dx.doi.org/10.1590/S000137652011000400019. PMid:22146960.

Engel, F., Attermeyer, K., Ayala, A.I., Fischer, H., Kirchesch, V., Pierson, D.C., \& Weyhenmeyer, G.A., 2019. Phytoplankton gross primary production increases along cascading impoundments in a temperate, low-discharge river: insights from high frequency water quality monitoring. Sci. Rep., 9(1), 6701. http://dx.doi.org/10.1038/s41598-01943008-w. PMid:31040329.

Ferrão-Filho, A.S., Domingos, P., \& Azevedo, S.M.F.O., 2002. Influences of a Microcystis aeruginosa bloom on zooplankton populations in Jacarepaguli Lagoon (Rio de Janeiro, Brazil). Limnologica, 32(4), 295-308. http://dx.doi.org/10.1016/S0075-9511(02)80021-4.

Fialkowska, E., \& Pajdak-Stós, A., 2002. Dependence of cyanobacteria defense mode on grazer pressure. Aquat. Microb. Ecol., 27, 149-157. http://dx.doi. org/10.3354/ame027149.

Golterman, H.L., Clymo, R.S., \& Ohnstad, M.A.M., Methods for physical and chemical analysis of freshwater (2nd ed.). Oxford: Blackwell Scientific Publication, 1978.

Jati, S., Bortolini, J.C., \& Train, S., 2017b. Mixotrophic species influencing phytoplankton community structuring during the filling phase of a subtropical reservoir. Braz. J. Bot., 40(4), 933-941. http://dx.doi. org/10.1007/s40415-017-0407-y.

Jati, S., Bortolini, J.C., Moresco, G.A., Paula, A.C.M., Rodrigues, L.C., Iatskiu, P., Pineda, A., Zanco, B.F., Silva, M.V., \& Souza, Y.R., 2017a. Phytoplankton community in the last undammed stretch of the Paraná River: considerations on the distance from the dam. Acta Limnol. Bras., 29, e112. http://dx.doi. org/10.1590/s2179-975x4017.

Kruk, C., \& Segura, A.M., 2012. The habitat template of phytoplankton morphology-based functional groups. Hydrobiologia, 698(1), 191-202. http:// dx.doi.org/10.1007/s10750-012-1072-6.

Lachi, G.B., \& Sipaúba-Tavares, L., 2008. Qualidade da água e composição fitoplanctônica de um viveiro de piscicultura utilizado para fins de pesca esportiva e irrigação. São Paulo. Bol. Inst. Pesca, 34, 29-38. 
Lewis Junior, W.M., 1976. Surface/volume ratio: implications for phytoplankton morphology. Science, 192(4242), 885-887. http://dx.doi.org/10.1126/ science.192.4242.885. PMid:17817763.

Ling, T.C., 2013. Tomografia computadorizada de raios-x aplicada à análize da qualidade ambiental de solo entorno da Usina Hidrelétrica de Ilha SolteiraSP [Master dissertation]. São Carlos: Escola de Engenharia de São Carlos-Universidade de São Paulo (EESC/USP).

Mackereth, F.Y.H., Heron, J.R., \& Tailing, J.F., Water analysis: some revised methods for limnologists. Amblesie: freshwater biological association. Kendal: Titus Wilson and Sons Ltda. 1978.

Marengo, J.A., Nobre, C.A., Seluchi, M.E., Cuartas, A., Alves, L.M., Mendiondo, E.M., Obregón, G., \& Sampaio, G., 2015. A seca e a crise hídrica de 20142015 em São Paulo. Rev. USP, (106), 31-44. http:// dx.doi.org/10.11606/issn.2316-9036.v0i106p31-44.

Marques, E.T., Gunkel, G., \& Sobral, M.C., 2019. Management of tropical river basins and reservoirs under water stress: experiences from Northeast Brazil. Environments, 6(6), 62. htp://dx.doi.org/10.3390/ environments6060062.

Meira, B.R., Lansac-Tôha, F.M., Segovia, B.T., Oliveira, F.R., Buosi, P.R.B., Jati, S., Rodrigues, L.C., LansacTôha, F.A., \& Machado-Velho, L.F., 2017. Abundance and size structure of planktonic protist communities in a Neotropical floodplain: effects of top-down and bottom-up controls. Acta Limnol. Bras., 29, e104. http://dx.doi.org/10.1590/s2179-975x6117.

Moura, A.N., Severiano, J.S., Tavares, N.K.A., \& Dantas, E.W., 2013. The role of a cascade of reservoirs and seasonal variation in the phytoplankton structure in a tropical river. Braz. J. Biol., 73(2), 291-298. http:// dx.doi.org/10.1590/S1519-69842013000200009. PMid:23917556.

Naselli-Flores, L., Padisák, J., \& Albay, M., 2007. Shape and size in phytoplankton ecology: do they matter? Hydrobiologia, 578(1), 157-161. http://dx.doi. org/10.1007/s10750-006-2815-z.

Nogueira, M.G., Ferrareze, M., Moreira, M.L., \& Gouvêa, R.M., 2010. Phytoplankton assemblages in a reservoir cascade of a large tropical - subtropical river (SE, Brazil). Braz. J. Biol., 70(3 Suppl.), 781-793. http://dx.doi.org/10.1590/S151969842010000400009. PMid:21085783.

Oksanen, J., Blanchet, F.G., Friendly, M., Kindt, R., Legendre, P., Mcglinn, D., Minchin, P.R., O’Hara, R.B., Simpson, G.L., Solymos, P., Henry, M., Stevens, H., Szoecs, E., \& Wagner, H., 2017. Vegan: Community Ecology Package. R package version 2.45 [online]. Retrieved in 2019, Jan. 23, from http:// CRAN.R-project.org/package=vegan

Padisák, J., Barbosa, F.A.R., Borbély, G., Borics, G., Chorus, I., Espindola, E.L.G., Heinze, R., Rocha, O.,
Törökné, A.K., \& Vasas, G., 2000. Phytoplankton composition, biodiversity and a pilot survey of toxic cyanoprokaryotes in a large cascading reservoir system (Tietê basin, Brazil). Internationale Vereinigung für theoretische und angewandte Limnologie. Verhandlungen, 27(5), 2734-2742.

Padisák, J., Crossetti, L.O., \& Naselli-Flores, L., 2009. Use and misuse in the application of the phytoplankton functional classification: a critical review with updates. Hydrobiologia, 621(1), 1-19. http://dx.doi.org/10.1007/s10750-008-9645-0.

Panosso, R., Carlsson, P., Kozlowsky-Suzuki, S., Azevedo, S.M.F.O., \& Granéli, E., 2003. Effect of grazing by a neotropical copepod, Notodiaptomus, on a natural cyanobacterial assemblage and on toxic and non-toxic cyanobacterial strains. J. Plankton Res., 25(9), 1169 1175. http://dx.doi.org/10.1093/plankt/25.9.1169.

Perbiche-Neves, G., Ferreira, R.A.R., \& Nogueira, M.G., 2011. Phytoplankton structure in two contrasting cascade reservoirs (Paranapanema River, Southeast Brazil). Biologia, 66(6), 967-976. http://dx.doi. org/10.2478/s11756-011-0107-1.

Poff, N.L., 1997. Landscape filters and species traits: towards mechanistic understanding and prediction in stream ecology. J. N. Am. Benthol. Soc., 16(2), 391-409. http://dx.doi.org/10.2307/1468026.

R Development Core Team, 2017. R: A language and environment for statistical computing [online]. Vienna: R Foundation for Statistical Computing. Retrieved in 2019, Jan. 23, from http://www.Rproject.org/.

Reynolds, C.S., 2006. The ecology of phytoplankton. Cambridge: Cambridge University Press.

Reynolds, C.S., Huszar, V.L., Kruk, M., Naselli-Flores, L.C., \& Melo, S., 2002. Towards a functional classification of the freshwater phytoplankton. J. Plankton Res., 24(5), 417-428. http://dx.doi. org/10.1093/plankt/24.5.417.

Silva, C.A., Train, S., \& Rodrigues, L.C., 2005. Phytoplankton assemblages in a Brazilian subtropical cascading reservoir system. Hydrobiologia, 537(1-3), 99-109. http://dx.doi. org/10.1007/s10750-004-2552-0.

Soares, M.C., Marinho, M.M., Huszar, V.L.M., Branco, C.W.C., \& Azevedo, S.M.F.O., 2008. The effects of water retention time and watershed features on the limnology of two tropical reservoirs in Brazil. Lakes Reservoirs: Res. Manage., 13(4), 257-269. http:// dx.doi.org/10.1111/j.1440-1770.2008.00379.x.

Stanford, J.A., \& Ward, J.V., 2001. Revising the serial discontinuity concept. Regul. Rivers Res. Manage., 17(4-5), 303-310. http://dx.doi.org/10.1002/rrr.659.

Stevaux, J.C., Martins, D.P., \& Meurer, M., 2009. Changes in a large regulated tropical river: The Paraná River downstream from the Porto Primavera Dam, Brazil. Geomorphology, 113(3-4), 230-238. https:// dx.doi.org/10.1016/j.geomorph.2009.03.015. 
Sun, J., \& Liu, D., 2003. Geometric models for calculating cell biovolume and surface area for phytoplankton. J. Plankton Res., 25(11), 1331-1346. http://dx.doi.org/10.1093/plankt/fbg096.

Tang, C., Sun, B., Yu, K., Shi, J., Liu, M., Jiang, T., Huo, Y., \& He, P., 2018. Environmental triggers of a Microcystis (Cyanobacteria) bloom in an artificial lagoon of Hangzhou Bay, China. Mar. Pollut. Bull., 135, 776-782. http://dx.doi.org/10.1016/j. marpolbul.2018.08.005. PMid:30301097.

Thomaz, S.M., Bini, L.M., \& Bozelli, R.L., 2007. Floods increase similarity among aquatic habitats in riverfloodplain systems. Hydrobiologia, 579(1), 1-13. http://dx.doi.org/10.1007/s10750-006-0285-y.

Tundisi, J.G., Matsumura-Tundisi, T., \& Rocha, O., 1999. Theoretical basis for reservoir management. In: Tundisi, J. G. \& Straskraba M., eds. Theoretical Reservoir Ecology and its Applications. São Carlos: International Institute of Ecology, Brazilian Academy of Sciences and Backhuys Publishers, 505-528.

Tundisi, J.G., Matsumura-Tundisi, T., \& Tundisi, J.E.M., 2008. Reservoirs and human wellbeing: new challenges for evaluating impacts and benefits in the neotropics. Braz. J. Biol. 68(4 Suppl.), 1133-1135.
PMid:19197483. http://dx.doi.org/10.1590/S151969842008000500020 .

Utermöhl, H., 1958. Zur Vervollkommnung der quantitativen phytoplankton-methodic. Mitt. d. internat. vereinig. of. Limnol., 9, 1-39.

Winemiller, K.O., McIntyre, P.B., Castello, L., FluetChouinard, E., Giarrizzo, T., Nam, S., Baird, I.G., Darwall, W., Lujan, N.K., Harrison, I., Stiassny, M.L.J., Silvano, R.A.M., Fitzgerald, D.B., Pelicice, F.M., Agostinho, A.A., Gomes, L.C., Albert, J.S., Baran, E., Petrere Junior, M., Zarfl, C., Mulligan, M., Sullivan, J.P., Arantes, C.C., Sousa, L.M., Koning, A.A., Hoeinghaus, D.J., Sabaj, M., Lundberg, J.G., Armbruster, J., Thieme, M.L., Petry, P., Zuanon, J., Vilara, G.T., Snoeks, J., Ou, C., Rainboth, W., Pavanelli, C.S., Akama, A., Soesbergen, A., \& Sáenz, L., 2016. Balancing hydropower and biodiversity in the Amazon, Congo, and Mekong. Science, 351(6269), 128-129. http://dx.doi.org/10.1126/ science.aac7082. PMid:26744397.

Received: 15 July 2021 Accepted: 12 November 2021

Associate Editor: Carla Ferragut. 